\title{
High performance curricular management at the Technological Institute of Campeche
}

\section{Gestión curricular de alto desempeño en el Instituto Tecnológico de Campeche}

\author{
ORTEGA-RODRÍGUEZ, Ana Luisa †*1, LEGORRETA-BARRANCOS Leydi Elena ${ }^{1}$, RODRÍGUEZ- \\ CHUC, Carmen Del Socorro ${ }^{1}$ and LÓPEZ-PONCE, María Eugenia ${ }^{2}$
}

${ }^{1}$ Instituto Tecnológico de Campeche

${ }^{2}$ Instituto Tecnológico Superior de Calkiní en el Estado de Campeche

ID $1^{\text {st }}$ Author: Ortega-Rodríguez, Ana Luisa / ORC ID: 0000-0002-0134-2008, CVU CONACYT ID: 228237

ID $1^{\text {st }}$ Coauthor: Legorreta-Barrancos Leydi Elena / ORC ID: 0000-0002-8918-4226, CVU CONACYT ID: 725501

ID $2^{\text {nd }}$ Coauthor: Rodríguez-Chuc, Carmen Del Socorro / ORC ID: 0000-0002-3587-4264, CVU CONACYT ID: 280251

ID $3^{\text {rd }}$ Coauthor: López-Ponce, María Eugenia / ORC ID: 0000-0001-7030-1843, CVU CONACYT ID: 503775

DOI: $10.35429 /$ EJC.2019.9.5.15.24

Received September 18, 2019; Accepted Decrmber 30, 2019

Abstract

Higher Education Institutions (HEI) face challenges to fulfill their substantive function of educating and training people; within this educational process, there are factors that affect the achievement of academic objectives embodied in the school curriculum of various programs of the education system. An adequate curricular structure guarantees that the practices carried out in the classroom are intentional, systematic and secure learning; this implies the design and implementation of an innovative curricular proposal, from the planning of the teaching-learning process to the evaluation. The curricular management is one of the strategic processes of HEIs, which operationalizes the public education policies in the state, where the curriculum is key in the Quality of Higher Education, because it considers the needs, problems and social interests, through the development of professional skills of students, in order to train professionals that contribute to national development. The curriculum, as a process, operates according to the school context from the perception of the teacher and the administration, tracing a clear link between: the curricular management and the classroom processes, the support networks with the dimensions of the TecNM model to be aligned and focused on high performance.

Curricular management, Curricular policies, Educational management

\section{Resumen}

Las Instituciones de Educación Superior (IES), enfrentan retos por cumplir con su función sustantiva de educar y de formar personas; dentro de este proceso educativo, existen factores que inciden en el logro de objetivos académicos plasmados en el currículum escolar de los distintos programas del sistema educativo. Una adecuada estructura curricular garantiza que las prácticas realizadas en el aula, sean intencionadas, sistemáticas y aseguran el aprendizaje; esto implica el diseño e implementación de una propuesta curricular innovadora desde la planeación del proceso de enseñanza - aprendizaje hasta la evaluación. La gestión curricular es uno de los procesos estratégicos de las IES, que operacionaliza las políticas públicas educativas vigentes del estado, donde el currículo es clave en la calidad de la educación superior, porque considera las necesidades, problemas e intereses sociales, a través del desarrollo de competencias profesionales de los estudiantes, a fin de formar profesionales que contribuyan al desarrollo nacional. El currículum como proceso, opera en función del contexto escolar desde la percepción del profesor y de la dirección, marcando una clara vinculación entre: la gestión curricular, los procesos áulicos y las redes de apoyo con las dimensiones del modelo del TecNM para alinearse y orientarse al alto desempeño.

Gestión curricular, Políticas curriculares, Gestión educativa

Citation: ORTEGA-RODRÍGUEZ, Ana Luisa, LEGORRETA-BARRANCOS Leydi Elena, RODRÍGUEZ-CHUC, Carmen Del Socorro and LÓPEZ-PONCE, María Eugenia. High performance curricular management at the Technological Institute of Campeche. Journal-Republic of Colombia. 2019. 5-8: 15-24

$\uparrow$ Researcher contributing as first author. 


\section{Introduction}

Education is a fundamental and important part of the socioeconomic and sustainable development of any society, since it provides access to better living standards. However, in Mexico, there are problems such as educational lag, obsolete plans and programs, insufficient budget, dropout, school failure and low academic level of teachers. Thus, the panorama results complex, since education must favor social mobility, forming critical human beings capable of living in society, participating responsibly in the definition of transformation processes within the political-social context.

This formation is part of the curricular development of HEIs, where its graduates are human capital to increase productive competitiveness in organizations, for the management of knowledge and science, contributing to the development of the country's intellectual capital. This central role of education in the development of nations, indicates that it is a complex system, the achievements of which have their most direct and palpable expression in the results of student learning, organized in a synchronized way in a curriculum that requires a systemic order and high performance curricular management, where an alignment of the microsystem to the macrosystem takes place.

This is the case of the Technological Institute of Campeche (IT Campeche), which is part of the National Technological of Mexico (TecNM), which represents an institutional challenge when trying to advance in all the dimensions of the educational model by competences, but in coordination as another component of the TecNM when analyzing the results obtained.

\section{Institutional Context}

Recent research indicates that quality education is essential so that the population participates fully in economic and political institutions, an essential part for democracy and economic development (Carnoy, 2008). Especially in those sectors, in which educational centers are inserted in areas that do not provide them with all the necessary conditions for their complete social development, this is expressed in the difficulties of access by socioeconomic level, reflected in the education quality.
The structure of the TecNM curricular model is based on the notion of the curriculum as an integrative training project and on the concepts of professional training, learning and educational practice, giving meaning to educational content, to the work of teachers and students, to didactic strategies, to educational processes and products, as well as to the design, implementation, development, monitoring and evaluation of academic programs.

The TecNM is a decentralized administrative body of the Ministry of Public Education (SEP, for its acronym in Spanish), with technical, academic and management autonomy, which has 266 institutions, of which 126 are Federal Technological Institutes, 134 Decentralized Technological Institutes, 4 Regional Centers of Optimization and Team Development (CRODE, for its acronym in Spanish), an Interdisciplinary Center for Research and Teaching in Technical Education (CIIDET, for its acronym in Spanish) and a National Center for Research and Technological Development (CENIDET, for its acronym in Spanish).

In these Institutes, located throughout the Mexican territory, attend approximately 556,270 undergraduate and graduate students. This represents $13 \%$ of higher education students in Mexico. To satisfy the student population, there are 28,135 teachers, offering 43 plans and programs with a focus on competences. This educational offer has a great impact, given that 4 out of 10 engineering professionals are trained in TecNM (DGEST, 2012).

These data show that the TecNM is a system where some Institutes are already consolidated and others are still in process, which makes it a leading Institution in the training of engineering professionals. Its curricular model considers the following:

a. Being consistent in the general training of the engineering professional.

b. Being flexible and adapt to the diversity of the areas of specialization required in different economic regions of the country.

c. Incorporating the use of information and communication technologies. 
The TecNM curriculuar model is flexible and incorporates the integral nature of knowledge, knowing-how-to-do and how-to-be. This model is used for curricular design and innovation of all its study plans and programs with a focus on professional competences, to meet the needs of the social, scientific, technological, economic, cultural and human development in Mexico.

The Specialty and the Professional Residence aims at the incorporation of innovative curricular strategies that allow a strengthening of the development of professional competences through modular integrative projects and dual school-company education, promoting the constant updating of the Academies in the emerging technologies and practices of the different areas of knowledge, for a better specialized professional training of greater flexibility in the formation of highly qualified human capital in the different areas of engineering knowledge.

Complementary Activities are a curricular space, with a value of 5 academic credits, which allows learning based on significant experiences and national or international cultural, sports and social activities that complement the student's professional training throughout their study plan.

This curricular model includes the training and development of the competences established in the professional profile in an ideal period of nine semesters and promotes integral graduation, favoring the indexes of terminal efficiency, characterized by the following aspects:

1. 1.Development and training of professional skills.

2. Greater flexibility.

3. Transfer and mobility.

4. Integral graduation.

5. Development of skills in the area of mathematics, research methodology, ethics and sustainable development.

6. Specialization in more specific skills in the area of emerging and leading-edge knowledge.

7. Application of professional skills through the resolution of a real context problem.

8. Multi-accreditation.

9. Multiculturalism.
10. Use of information and communication technologies in the development of professional skills.

The Educational Model for the 21st Century of TecNM (2015) is comprised of three large dimensions: the philosophical, which focuses the attention of the model on the human being; the academic, that integrates the parameters of reference of professional formation, the conception of learning and its conditions, as well as the standards of the educational practice in each of the Technological Institutes; and the organizational, which contributes to the fulfillment of the goals of the model and guarantees that the resources are substantially dedicated to education purposes.

The study programs incorporate contents of a conceptual, procedural and attitudinal nature, coherently consolidates, in order to enrich the educational work and achieve synergistic results (DGEST, 2012):

Conceptual contents -knowledge- are theoretical constructs, including: concepts, definitions, categories, laws, principles, postulates, theorems and models. They are disciplinary in nature to describe, explain, predict events, phenomena, causal relations and professional training processes for the ethical exercise of the profession.

The procedural contents -the know-howto-do- are executions of processes, methods, techniques, and procedures related to the mastery and use of different languages, algorithms and heuristics, in which thinking strategies for the creation and design of devices, machines and technological objects for solving technological production problems are of paramount importance.

Attitudinal contents -the know-how-tobe- are habitual guidelines for deontological action which are present in the application of conceptual and procedural contents, as well as in professional performance.

Another important aspect was the definition of credits from the Academic Credit Allocation and Transfer System (SATCA, for its acronym in Spanish), which defines credit as the unit of measurement of students' academic work. 
In the teaching and supervised professional field work criteria and other individual or independent learning activities, including credits from other HEIs, called multiaccreditation (ANUIES, 2007). Table 1 shows the alignment of the academic credit allocation criteria of the TecNM curricula.

\begin{tabular}{|c|c|c|}
\hline Criteria & Activities & $\begin{array}{l}\text { Credit } \\
\text { hours }\end{array}$ \\
\hline $\begin{array}{l}\text { Teaching: Classes in } \\
\text { front of the group in } \\
\text { a theoretical- } \\
\text { practical way on-site } \\
\text { or remotely. }\end{array}$ & $\begin{array}{l}\text { Classes, } \\
\text { laboratories, } \\
\text { seminars, } \\
\text { workshops, courses, } \\
\text { among others. }\end{array}$ & $\begin{array}{l}16 \\
\text { hours=1 } \\
\text { credit }\end{array}$ \\
\hline $\begin{array}{l}\text { Supervised } \\
\text { professional field } \\
\text { work: work done in } \\
\text { the professional } \\
\text { residence and the } \\
\text { social service. }\end{array}$ & $\begin{array}{l}\text { Professional } \\
\text { residence and social } \\
\text { service. }\end{array}$ & $\begin{array}{l}50 \\
\text { hours }=1 \\
\text { credit }\end{array}$ \\
\hline $\begin{array}{l}\text { Complementary } \\
\text { credits: } \\
\text { Individual or } \\
\text { independent learning } \\
\text { activities through } \\
\text { tutoring. }\end{array}$ & 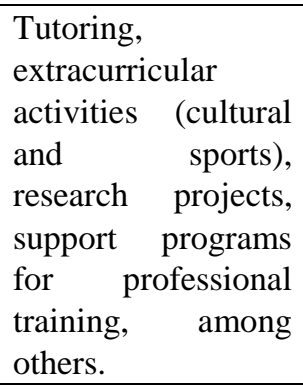 & $\begin{array}{l}20 \\
\text { hours }=1 \\
\text { credit }\end{array}$ \\
\hline
\end{tabular}

Tabla 1 Criterios para la asignación de créditos en el TecNM

Fuente: DGEST (2012)

Currently, the 43 study plans have 260 credits, distributed in six curricular moments aligned with the three SATCA criteria:

$\begin{array}{ll}\text { 1. } & \text { Generic structure } \\ \text { 2. } & \text { Specialty } \\ \text { 3. } & \text { Social service } \\ \text { 4. } & \text { Professional residence } \\ \text { 5. } & \text { Complementary credits } \\ \text { 6. } & \text { Integral graduation }\end{array}$

As seen in Table 2, the block of generic structure and specialty must be adjusted in the established range, so that adding the other blocks always results in a total of 260 credits.

\begin{tabular}{|l|l|ll|}
\hline Curriculum block & \multicolumn{1}{|c|}{$\begin{array}{c}\text { Number } \\
\text { of credits }\end{array}$} & \multicolumn{2}{|c|}{$\begin{array}{l}\text { Criteria according to } \\
\text { SATCA }\end{array}$} \\
\hline Generic structure & $\begin{array}{l}200 \text { to } 210 \\
\text { credits }\end{array}$ & Teaching & \\
\hline Specialty & $\begin{array}{l}25 \text { to } 35 \\
\text { credits }\end{array}$ & Teaching & \\
\hline Social service & 10 credits & $\begin{array}{l}\text { Supervised } \\
\text { Professional }\end{array}$ & Field \\
Work & \\
\hline $\begin{array}{l}\text { Professional } \\
\text { residence }\end{array}$ & 10 credits & $\begin{array}{l}\text { Supervised } \\
\text { Professional }\end{array}$ & Field \\
Work & Complementary \\
\hline $\begin{array}{l}\text { Complementary } \\
\text { credits }\end{array}$ & 5 credits & $\begin{array}{l}\text { Comities } \\
\text { activities }\end{array}$ \\
\hline
\end{tabular}

Tabla 2 Estructura crediticia de los planes de estudio del TecNM

Fuente: DGEST, 2012

\section{High Performance Curricular Management}

This work considers curricular management as a permanent process that takes place in interrelated stages, in which each of them characterizes a part of the process as a whole, influencing each other among its components (Rodríguez \& Concepción, 2013).

The structure of the curriculum is a twodimensional process; the macro-design that plans the general training curriculum by a commission designated by the organizational structure itself; and another of microdesign that the teacher builds, related to the content planning of the programs that make up the curriculum (Fuentes \& Lucio, 2009). From the globalizing perspective of the four knowledges declared by UNESCO correspond to knowledge, skills, attitudes and values that students acquire in the process of integral formation throughout their lives. This knowledge contains a coherent relationship with the instructive, educational and developmental dimensions of the pedagogical category of training, which implies a single process in which all its components are integrated (Concepción \& Rodríguez, 2013).

The challenge in this case, for the fundamental actors of the formative process, requires the student the integrality in learning the knowledge, skills, attitudes, values and knowing how to live together to share and perform in a socio-professional ethical environment (Tejeda \& Sánchez, 2012); and to the teacher, the task of revaluating and rethinking their role in curriculum development, as the process through which they reflect to improve their teaching; it poses the teacher as a researcher of their own practice (Elliott, 2014).

ORTEGA-RODRÍGUEZ, Ana Luisa, LEGORRETA-BARRANCOS Leydi Elena, RODRÍGUEZ-CHUC, Carmen Del Socorro and LÓPEZ-PONCE, María Eugenia. High performance curricular management at the María Eugenia. High performance curricular management at the
Technological Institute of Campeche. Journal-Republic of Colombia. 2019 
In this way, in order to fulfill the challenge and goal of education, schools, as the first link in the system, acquire their meaning and define their mission: to disseminate the knowledge, norms, values and ideas with which it is intended to model society, using as a strategic intervention action the systematic and organized addition of a set of basic knowledge (cognitive area), skills and abilities (sensomotor area), aptitudes and values (axiological area) to what we call curriculum, through which they aim to model the behavior and awareness of the individuals in the search for the common good (Arroyo, 2009).

Within the factors and agents involved in schools, and their function, we find the pedagogical leaderships, which involve a management and teaching duty (Carriego, 2006), oriented to the curricular management or administration of the curriculum.

These leaderships, focused on pedagogics and curricula, among other functions, would allow schools inserted in vulnerable contexts to harmonize the cultural codes implicit in the curriculum with those of their students, generating processes of organization and monitoring of teaching (Sáez, 2009).

In this context, we request a renewal of the paradigm that prevails in the IT Campeche, in the organizational, technical and social system as a whole, since it directly impacts the projects of the various educational programs taught, and which are currently not totally effective in relation to curricular management, where there is a management leadership exercised by the Headmaster, Deputy Directors, Academic Chiefs and Coordinators, and an academic leadership exercised by teachers.

The organizational dimension (TecNM, 2015) in its macrosystem aspect is determined by the Quality Management System, in which the strategic processes are defined for optimal results, and as an IT Campeche microsystem, it must establish its procedures aligned to the TecNM as a component, to make administrative practices efficient and achieve the established indicators.
However, despite this standardization of the organizational processes, in IT Campeche the lack of managerial professionalization can be perceived, which leads to a reactive management marked by omissions or application of personal criteria in decision making; making students turn to professors recognized for their knowledge of administrative processes and practices, which favors a work environment characterized by disqualification towards these teachers.

A high-performance curriculum management would be designed to assume transformative management leadership, based on a managerial professionalization that establishes a shared worldview, develop staff, redesign the organization and manage instruction. The guiding mission must allow the generation of organizational conditions, to favor a harmonious coexistence within the institution, with the generation of a positive work environment oriented towards learning and knowledge generation.

The different tasks corresponding to the management field allow teachers to provide the necessary support to carry out the teachinglearning processes effectively, this requires an active academic drive that permanently coordinates and supports the pedagogical work they do, which implies that in the institution there is an academic and pedagogical leadership committed to planning, stimulating, supervising and monitoring the teaching-learning process, which includes working directly with teachers in the areas of curriculum design and implementation, teaching and evaluation.

The Headmaster's knowledge about effective pedagogical practices is a key element for school improvement and the other element being the efficient and effective application of the processes in curricular management by his management team, academic leaders, coordinators and teachers, to achieve coordination of the times in the curricular implementation, allowing to optimize the teaching hours available for the achievement of the academic and training objectives of the different educational programs of the institution. This implies assigning work schedules, specifying teaching times through normative policies and procedures, organizing teachers in their pedagogical work, focusing work towards learning goals and thus being able to achieve the planned teaching activities. 
On the other hand, the curricular conduction requires that the school organization has guidelines for the pedagogical work of the teachers, which implies agreeing and coordinating with them criteria and standards in aspects such as planning, evaluation or homework assignment policy (Weinstein, 2009). It is important that teachers have a clear vision on how teaching should be implemented and didactic strategies defined, so that within the Academies a collegiate work can be developed, respecting the common pedagogical guidelines to do it in a consistent manner between levels and areas of learning.

The above also includes advising teachers on the use of best practices and teaching methodologies, ensuring the provision of pedagogical and didactic resources for curricular implementation and evaluation, which also implies the provision of learning materials and/or resources that effectively support the achievement of educational objectives (Weinstein \& Muñoz, 2012).

\section{Proposal}

Undoubtedly, the current curricular structure, bounded by an evaluation system that prioritizes the reproduction and reduction of contents that have to be addressed in a certain time and place, in addition to other conditions of culture and school organization, needs to reformulate the current curricular structure so that, instead of limiting, it encourages teachers to make the appropriate adaptations that favor key and meaningful learning.

Through learning activities aimed at the students for them to analyze, explain causes, relate and formulate hypotheses, among others; preventing the learning process from concentrating on the acquisition of selected content, that is, in obtaining a simple list of data by selective memorization.

In these cases, learning becomes a burden for the student, a task to get rid of, and for the teacher a problem of time that prevents them from devoting fully to the task, emphasizing the completion of the program at the expense of depth (Biggs, 2010).
As a result of the proposal to design effective pedagogical practices in a collegial way within the Academy, in the design of these practices, Significant Learning, Located Learning and Socio-Emotional Learning were taken into account, since the study programs suggest that teachers elaborate them for themselves.

However, when reviewing the course management of the professors of the Academy of Administration, no formalized practice was found in the teaching instrumentation delivered to the academic department, despite the suggestion contained in the study programs to apply practices in the subjects of the common areas in Administration Engineering (AE) and Engineering in Business Management (EBM).

In this review, only one highperformance integrative practice was found (Ortega, Suárez, Legorreta, López, 2015), which is applied only in the Interdisciplinary Specialty of the EBM educational program and in common subjects. Considering that our study programs incorporate content of a conceptual, procedural and attitudinal nature, it was important to strengthen the attitudinal training of students, since the required learning for the development of their professional competences comprise the following:

$\begin{array}{ll}- & \text { Self-awareness } \\ - & \text { Self-management } \\ - & \text { Social conscience } \\ - & \text { Skills to interact with others } \\ - & \text { Responsible decision making }\end{array}$

Therefore, the types of learning under which the proposal was made are presented below.

\section{Significant learning}

The most relevant principle of significant learning is that all new knowledge must be related to the previous one. The most important factor influencing this learning is what the student already knows. It requires specific skills of the teacher to investigate what is the level of learning that the group of students has and what are the alternative conceptions they have. Therefore, it is recommended to apply a diagnostic evaluation, the results of which will be the starting point for the design or redesign of the learning strategies. 
The activity must contain such characteristics that the students have to generate interest in relation to the new material with their cognitive structure so that they have a disposition for learning.

\section{Located learning}

This approach has to do with the context and the reality in which the student grows and develops. It considers that located learning occurs when cognitive activity takes place within a contextualized, located and culturally significant practice.

Regarding the above, it is also pointed out that collaborative learning is the best strategy for students to participate productively in authentic shared cognitive practices.

The key is that the teacher can create the situation within the school context itself -or outside of it- where the student, while getting involved with their peers, also grows and learns while sharing their knowledge and skills in their own group. Meanwhile, students negotiate meanings, exchange information, talk about the problem to be solved, discuss and generate solution strategies, that is when they are really involved in activities that originate deep and meaningful learning (Soler, 2006).

Located learning occurs through authentic educational practices that are consistent, meaningful and purposeful. In this approach, the teacher designs learning environments or involves students in relevant contexts.

For this, it recovers principles of sociocultural learning since cognition is based on the premise that located knowledge is part and product of the activity, context and culture in which it is developed and used.

Next, eight models or procedures that favor located learning are mentioned, favoring the approach to real contexts and the reflective, critical, deep-thinking activities (Díaz, 2006).

1. Learning focused on solving authentic problems.

2. Case analysis.

3. Project method.

4. Practices located or learning in situ in real scenarios.

5. Service learning.
6. Work in cooperative teams.

7. Located exercises, proofs and simulations.

8. Learning mediated by information and communication technologies.

\section{Socio-emotional learning}

It is recognized that for the full development of the student or for their integral training, the development of socio-emotional skills must necessarily be favored, which should be reflected in the curriculum. The justification is that learning acquires meaning when it truly contributes to the full personal and social development of individuals, for which the following dimensions are included:

- Intellectual openness.

- $\quad$ Sense of responsibility.

- Self-knowledge.

- $\quad$ Team work and collaboration.

The key competence related to the development of students' socio-emotional skills is "learning to live together," along with "learning to learn," so a curriculum of key learning and areas of personal and social development will bring attention to the simultaneous processes of learning to learn and live together (SEP, 2016).

For all the above, the curricular aspect plays a fundamental role in the quality of HEIs and for the IT Campeche belonging to this system, the curriculum must be viewed as a process that operates in a very particular social and cultural context, different to that of the TecNM, forcing it to be recognized as part of a whole, but assuming the definition of its own components to achieve effective administration by optimizing the performance of its own resources.

The High Performance Curriculum Management should be seen as a formative and integrative process, characterized by the interaction and interrelation of all the elements of the teaching and learning process, the administration, the teachers, the students, the study plans and programs, the infrastructure, guidelines, school culture, among others. This proposal took into account the following components: 


\section{- Curricular Component \\ - Institutional Management Component \\ - $\quad$ Teaching Performance in the Classroom Component}

It should be clarified that this proposal focused, as a first approximation, on the Teaching Performance in the Classroom Component. The important point about this proposal is to provide teachers of the Administration Academy with a methodology for the design and implementation of high performance curricular practices, that favor the significant learning of students and their integral formation.

The fundamental objective is to provide the teacher with a methodological and pedagogical tool to design effective practices that favor relevant learning environments, placing students in a located context that connects them with their cognitive structure and cultural heritage, so that prior knowledge activate and perform their role according to the required learning activity.

In this classroom context, the logical and psychological disposition of the teacher and students flows naturally because it occurs in a social, cultural and emotional context that is usual for them; in a group that is committed to group learning.

The methodological proposal for high performance curricular practices of the Teaching Performance in the Classroom Component, with its corresponding design categories, is presented below:

\section{Teaching Performance in the Classroom Component}

Categories

1. Planning

- Content selection

- Professional competence

- Design of teaching strategies

- Selection of evaluation strategies

2. Class environment management

- Interpersonal relationships

- Group management
3. Curricular Management

- Disciplinary mastery of the subject

- Disciplinary mastery of the subjects

- Contextualization of the subject

- Contribution of the subject to the graduation profile

4. Teaching management

- Group organization

- Didactic resources

- Time management

- Student-student learning relationship

- Instructions and indications

- Feedback

- Directed / non-directed activities

5. Evaluation

- Self-evaluation

- Co-evaluation

- Heteroevaluation

\begin{tabular}{|l|l|l|l|}
\hline \multicolumn{1}{|c|}{ Categories } & Practice & Subject & Result \\
\hline 1.Planning & & & \\
\hline 2. Class & & & \\
Environment & & & \\
Management & & & \\
\hline 3. Curricular & & & \\
management & & & \\
\hline 4. Didactic & & & \\
management & & & \\
\hline 5.Evaluation & & & \\
\hline Total & & & \\
\hline
\end{tabular}

Table 3 Concentrator Chart

Source: Prepared by the authors, 2019

\section{Acknowledgments}

We recognize the Campeche Technological Institute and the Calkiní Higher Technological Institute for the support and facilities provided.

\section{Conclusions}

A successful curricular management within any educational institution must articulate all the organizational elements and align them towards the social and professional demands of the labor market; the academic conduction is conceived as a function of supervision and control towards the teacher by the administration authority; however, the direction of joint efforts is important and must be consistent with the view that academic leadership must be shared between the headmaster and other members of the team. 
Curriculum management should be seen as a process that constitutes a fundamental tool for programming and implementing pedagogical work in the classroom, planning and identifying the essential contents that students must learn, estimating the time required to ensure that they can be taught effectively, in a sequenced and organized way to optimize the learning experience.

Practices designed and implemented in the classroom are a pedagogical learning tool. Many times they become the solution in the educational situations in which students participate, allowing them to learn in a relevant context. It is an experience that involves thinking, affectivity and action.

It is important to mention the concept of learning obstacles, since they can prevent education from being inclusive with equity. Many times the learning barriers are in the very conditions of the educational offer in terms of infrastructure, for example, the state of the classroom, the students' access to at least one computer and if there is internet service.

\section{References}

Arroyo, J. (2009). Gestión directiva del currículum. Revista Electrónica Actualidades Investigativas en Educación, 9 (2), 1-17.

Asociación Nacional de Universidades e Instituciones de Educación Superior (ANUIES). (2007). Sistema de asignación y transferencia de créditos académicos. Mexico: Retrieved from http://www.uacj.mx/sa/ie/Documents/SATCA/ SATCAExtenso.pdf

Biggs, J. (2010). Calidad del aprendizaje universitario, Madrid, Narcea, 2010.

Carnoy, M. (2008). Mejorando la calidad y la equidad de la educación en América Latina. Retrieved on 7 September 2010 from: http://www.ceppe.cl/recursos/presentaciones

Carriego, C. (2006). Gestionar una escuela comprometida con las demandas de su tiempo. Revista Iberoamericana de Educación, 39 (2), 3.
Díaz Barriga, F.(2003). Cognición situada y estrategias para el aprendizaje significativo, Revista Electrónica de Investigación Educativa, 5(2). Available at http://redie.ens. uabc.mx/vol5no2/contenido-arceo.html. Date of consultation, September 10, 2016.

Díaz Barriga, F.(2006). Enseñanza situada. Vínculo entre la escuela y la vida, Mexico, McGraw Hill.

Dirección General de Educación Superior Tecnológica (DGEST). (2012). Anuario Estadístico 2012. Mexico

Elliott, S.N. Y Clifford, M. (2014). Principal assessment: Leadership behaviors known to influence schools and the learning of all students. (Document No. LS-5). Retrieved From http://ceedar.education.ufl.edu/wpcontent/uploads/2014/09/LS-5_FINAL_09-2614.pdf

Gamino-Carranza, A. y Acosta-González, M. G. (2016). Modelo curricular del Tecnológico Nacional de México. Revista Electrónica Educare, 20(1), 1-25. doi: http://dx.doi.org/10.15359/ree.20-1.10

Ortega, Ana, Suárez, Rosario, Legorreta, Leydi y López, María.(2015). Propuesta Metodológica de una práctica integradora para grupos de aprendizaje de alto desempeño. Revista de Sistemas y Gestión Educativa 2015, 2-5: 9931002

Rodríguez, Félix, Concepción, María Rita. (2013). La gestión curricular soportada en las TIC. Experiencia en la Universidad Autónoma del Caribe. III Congreso Iberoamericano y Nacional por una Educación de Calidad, Barranquilla, November 2013, Colombia.

Ruiz, José. (2005). Teoría del curriculum: Diseño, desarrollo e innovación curricular. Tercera edición. Editorial Universitas, SA, Madrid (Spain).

SEP (2016). Modelo Educativo, México, SEP,.

Soler, E.(2006). Constructivismo, Innovación y Enseñanza Efectiva, Caracas, Equinoccio. 
México, SEP, (s/f). Subsecretaría de Educación Media Superior. "Programa ConstruyeT 20142018. Fortalecer las capacidades de la escuela para promover el desarrollo integral de los jóvenes", Available at: www.construye-t.org. $\mathrm{mx} /$ resources/DocumentoConstruyeT.pdf

Tejeda, Rafael y Sánchez, Pedro. (2012). La formación basada en competencias profesionales en los contextos universitarios. Colección educativa Tiempos de aprender. Serie Vicerrectorado Académico. Editorial Mar Abierto. Manta (Ecuador).

TecNM (2015). Modelo Educativo para el S.XXI. Mexico, TecNM.

Weinstein, J. (2009). Liderazgo directivo, asignatura pendiente de la Reforma Educacional Chilena. Revista Estudios Sociales, 117, 123-148.

Weinstein, J., y Hernández, M. (2015). ¿Un centro nacional de liderazgo escolar en Chile? Antecedentes para su diseño. Santiago de Chile: Espacio Público.

Weinstein, J., Y Muñoz, G. (2012). ¿Qué sabemos sobre los directores de escuela en Chile. Santiago de Chile: Centro de Innovación en Educación de Fundación Chile y Centro de Estudios y Políticas y Prácticas en Educación. 